\title{
Değişken Ayar Sürelerine Sahip Bir Üretim Hattının Çizelgeleme Optimizasyonu
}

\author{
Ural Gökay ÇİÇEKLİa,b, Süleyman ZİLCİ c
}

\section{Özet}

Üretim çizelgeleme işletmelerin üretim planlama ve kontrol bölümlerinin başarısında çok önemli rol oynamaktadır. Çizelgeleme optimizasyonu, sahip olduğu çözüm uzayı nedeniyle çözümü zor ve zaman alan optimizasyon problemlerinden biridir. Kombinasyona dayalı zorluğundan geçmişten günümüze araştırmacıların ilgi odağı olmuştur. İlk araştırmacılar problemleri kesin matematiksel yöntemler ile çözmeye çalışırken, problemler karmaşıklaştıkça bu çözümler uygun zamanlarda sonuç vermediği görülmüştür. Bu nedenle, araştırmacılar çizelgeleme problemlerini çözmek için sezgisel ve meta sezgisel yöntemler geliştirmiştir. Bu çalışmada endüstriyel ürünler imalatı alanında faaliyet gösteren bir firmanın çok fonksiyonlu makinalardan oluşan bir üretim hattının optimizasyonu problemi ele alınmıştır. Çalışma kapsamında öncelikle üretim modeli oluşturulmuş, sonrasında ise genetik algoritma kullanılarak oluşturulan optimizasyon modeli ile çizelgeleme problemi çözülmeye çalışılmıştır.
Anahtar Kelimeler

Üretim Çizelgeleme

Genetik Algoritma

Boru Üretimi

Makale Hakkında

Geliş Tarihi: 19.09.2018

Kabul Tarihi: 26.03.2021

Doi: 10.18026/cbayarsos.789473

\section{Optimization of Production Line Schedule with Variable Setup Times}

\begin{abstract}
Production Scheduling plays a crucial role in the success of production planning and control departments of businesses. Scheduling optimization is one of the difficult and time-consuming optimization problems to solve due to the solution space. It has become the focus of researchers' interest due to its combination-based difficulty. While the first researchers tried to solve the problems with classical mathematical methods, these solutions were found not to work appropriately as the problems became more complicated. For this reason, researchers have developed heuristic and meta-heuristic methods to solve scheduling problems. In this study, the optimization problem of production line consists of a multifunctional machine operating in the industrial goods manufacturing field. First, the production model was created, and then the scheduling problem was tried to be solved by the optimization model created by using genetic algorithm.
\end{abstract}

Keywords

\author{
Production Scheduling \\ Genetic Algorithms \\ Pipe Production
}

\section{About Article}

Received: 19.09 .2018

Accepted: 26.03.2021

Doi: 10.18026/cbayarsos.789473 


\section{Giriş}

Günümüz pazar koşullarında firmaların rekabetçiliklerini korumak için müşterilerin teslimat, maliyet ve kalite beklentilerini karşılamak, hatta rakiplerinin sunduklarından daha iyi koşullar ile pazara hizmet etmek zorundadır. Zorlaşan bu koşulların yanında pazarların gittikçe daha fazla çeşitteki ürünü daha hızlı ve daha az miktarlarda talep etmesi ile firmaların üretim sistemlerini bu taleplere adapte etmeleri gerekmektedir. Pazar'dan gelen talepler doğrultusunda ortaya çıkan çok istasyonlu ve çok fonksiyonlu istasyonlardan oluşan esnek üretim hatları beraberinde daha kompleks planlama gereksinimleri getirmektedir.

Üretim planlama; üretim ortamındaki kaynakları en verimli biçimde kullanarak zaman, miktar, sürdürülebilir maliyetler ile müşterilerin taleplerini karşılayacak üretim faaliyetlerinin organize edilmesidir. Üretim planlama; şirket içi diğer planlamalar üzerinden koordine edilen tüm faaliyetleri bir arada bulunduran ve işletimine olanak sağlayan programlardan oluşan bir bütündür (Buzacott vd., 2012). Üretim Çizelgeleme ise, işletmelerin üretim planlama ve kontrol bölümlerinin başarısında çok önemli rol oynamaktadır. Çizelgeleme, ana üretim çizelgesi ile belirlenen üretim hedeflerine ulaşabilmek için belirlenen kısıtlar altında çeşitli is merkezlerinde, hangi isin ne zaman yapılacağına karar vermek için, imalat öncesi yapılan bir çizelge olarak nitelendirilmektedir.

\section{1. Üretim Çizelgeleme}

Çizelgeleme genellikle olaylar dizisinin bir parçası olan faaliyetlerin başlangıç zamanlarının, operasyon sürelerinin ve bitiş zamanlarının belirlenmesi, operasyonların birbirini izler şekilde siralanmasidir. (Kamauff, 2010, s. 159).

Graves (1981) üretim çizelgelemeyi, belirlenen bazı kriterleri en iyi şekilde karşılayabilmek için uygun üretim kaynakların belirli süre için tahsisi olarak tanımlamaktadır. Bir harmonik düzenleme konusu olan çizelgelemede, çıktıyı üretmek için doğru görevlerin doğru zamanda, doğru unsurlar ile yönetilmesinin sağlanması ile ilgilenilmektedir (Sheikh, 2003, s. 474). Çizelgeleme üretim işletmelerinde en önemli fonksiyonlardan birisi olarak görülmektedir. Çizelgeleme, üretim başlamadan önceki planlamanın son aşamasıdır (Russell ve Taylor, 2000, s. 701).

Çizelgeleme birçok üretim ve servis endüstrisinde rutinde kullanılan bir karar verme sürecidir. Çizelgeleme kaynakların gerekli operasyonların istenilen zamanda ve amaçlanan bir veya birden fazla koşulun gerçekleştirilmesi için atanması işlemidir. Çizelgelemenin toplam tamamlanma süresinin minimizasyonu veya terminlere göre en az geciken iş ile üretimin tamamlanması gibi amaçladığı birçok farklı koşul da bulunabilmektedir.

\section{Üretim Çizelgeleme Fonksiyonu}

Üretim veya servis sistemlerinde çizelgeleme fonksiyonu birçok diğer fonksiyon ile iletişim halinde olmak zorundadir.

Genel bir üretim tesisini ele aldığımızda üretime verilen siparişlerin teslim tarihlerini göz önünde bulundurarak detaylı iş planlarına dönüştürülmesi gerekmektedir. Genellikle bu işler planlanan iş istasyonlarında belirlenen sıra ile gerçekleştirilmektedir. İş planlarında bulunan operasyonlar kimi zaman üretimde beklenmeyen makine arıaları veya işlemlerin 
öngörülemeyecek kadar uzun sürelerde gerçekleştirilebilmelerinden dolayı gecikmeler yaşanabilmektedir. Bu gibi koşullar altında çizelgeleme bütünsel operasyonun verimliliğini korumak ve sürecin kontrol altında tutulması için önemli bir rol oynamaktadır.

Üretim çizelgeleme optimizasyonu toplam üretim süresini ve(veya) makinaların kullanım oranlarını müşteri terminlerini dikkate alarak en yüksek düzeye ulaştırma, dolayısıyla da toplam maliyeti optimize etmek amaciyla üretim süresi ve teslimat parametrelerini optimize etme işlemidir. Üretim çizelgeleme problemleri NP-zor problem sınıfında bulunduğundan, problem boyutu büyüdükçe çözümü analitik yöntemlerle mümkün olmadığından onların yerine sezgisel yöntemler kullanılmaktadır (Temiz ve Erol, 2007, s. 856). Bu nedenle, araştırmacılar çizelgeleme problemlerini çözmek için sezgisel ve metasezgisel yöntemler geliştirmiştir.

Metasezgisel yöntemlerin amacı çözüm uzayının optimum çözünme en olası bölgelerinde arama yaparak yerel optimumlardan kurtulmak, global optimuma yakın sonuçlar bulmaktır. Metasezgisel yöntemler, klasik sezgisel yöntemlerin doğadan ilham alarak geliştirilmiş hali olarak görülebilir (Laporte vd., 2000). Metasezgisel optimizasyon algoritmaları deterministik olmayan yöntemlerdir ve en iyi çözümü garanti etmemekle birlikte, çözüm uzayının çok büyük olduğu, denenmesi gereken olasılıkların fazla olduğu durumlarda kabul edilebilir bir süre ve deneme ile kabul edilebilir seviyede iyi bir çözüm bulmaktadırlar.

\section{Genetik Algoritma}

Günümüzün karmaşık ve zor koşulları problemlere hızlı ve kolay çözüm vermek için özellikle sert (hard) optimizasyon teknikleri yerine, yumuşak hesaplama (soft computing) ve evrimsel algoritma (evolutionary algorithm) gibi yeni çözüm yöntemleri arayışına neden olmuştur (Emel ve Taşkın, 2002, s. 130). Bu evrimsel algoritmalardan en çok kullanılanlardan biri olan genetik algoritmalar (GA), doğal seçim ve doğal genetiklerin ikisinden esinlenmiş sayısal optimizasyon algoritmalarıdır (Coley, 1999, s. 1).

1859' da Charles Darwin'in “Türlerin Kökeni” kitabında bulunan "Survival of the fittest - En iyinin hayatta kalması" ilkesi evrimsel hesaplamanın çıkış noktası olarak kabul edilmektedir. (Sivanandam ve Deepa, 2008, s. 1; Gonçalves, de Magalhães Mendes ve Resende, 2005, s. 80). Doğal seleksiyon ile ortam koşullarına adapte olabilen canlı türlerinin sayısı artarak devam etmekte iken herhangi bir sebeple ortam koşullarına uyumlanamayan türlerin sayısı zamanla azalmaktadır. Zaman içinde ekosisteme bakıldığında her yeni nesil bir önceki jenerasyona kıyasla koşullara daha uyumlu olduğu söylenebilmektedir.

Genetik algoritma terimi ilk defa 1975 yılında Holland J.H. tarafından yayınlanan "Doğal ve Yapay Sistemlerde Adaptasyon" kitabında kullanılmıştır (Holland, 1975). Holland bu çalışmasında evrim teorisinin prensiplerinin optimizasyon problemleri çözümünde nasıl kullanılabileceğini açılamıştır. Bu çalışma Evrimsel Programlama (evolutionary programming (EP)), Evrim Stratejileri (evolution strategies (ES)), Yapay Yaşam (artificial life (AL)), Genetik Programlama (genetic programming (GP)) ve birçok bulunduğu ortama adapte olabilen donanım çalışmasına ön ayak olmuştur (Reeves ve Rowe, 2003, s. 2)

Evrimsel algoritmalar bu prensiplerin optimizasyon algoritmalarına uyarlanmış halidir. Arama algoritmalarında çözüm uzayında birçok farklı nokta bulunmaktadır ve görev bu noktalar arasındaki en iyisini bulmaktır. Çözüm uzayı görece küçük olan problemlerde en iyi 
çözümü bulmak için tüm noktaları denemek geçerli bir çözüm yolu olarak görülebilmektedir ancak çözüm uzayı problem yapılarına göre kolaylıkla her noktaya bakılabilecek büyüklügün üzerine çıkabilmektedir. Bu gibi durumlarda geleneksel arama algoritmalarının veya sezgisel yöntemlere başvurulmaktadır.

\section{Genetik Algoritma Terminolojisi ve Operatörleri}

Genetik algoritmalar optimizasyon problemlerinin çözümlerinin problemin bulunduğu ortamda bulunan bir birey olduğu metaforu üzerine kuruludur. Genetik algoritmalarda bireyler bulundukları ortamda bir bit veya sembol seti olarak tanımlanırlar. Popülasyon içinde kodlanmış bireylerin her biri, problemin çözümüne uygun kodlamasını kullanarak çözüm uzayında bir nokta olarak gösterilebilmektedir. Genetik algoritmalarda en iyi sonucu bulabilmek için popülasyon içindeki bireylere bir dizi operasyon uygulanmaktadır.

GA temel olarak aşağıdaki birbirini izleyen adımlardan oluşmaktadır(Hou, Ansari ve Ren 2014, s. 114):

1. Başlatma - Başlangıç popülasyonunu rastgele oluştur

2. Uygunluk Fonksiyonun Değerlendirilmesi - Popülasyondaki tüm bireyler için uygunluk fonksiyonunu hesapla

3. Genetik İşlemler - Genetik algoritma operatörlerini kullanarak ve uygunluk değerlerini inceleyerek yeni nesil oluştur.

4. Durdurma kriterini gerçekleşene kadar 2. ve 3. Adımları tekrarla

Bireyler: Popülasyon içindeki tekil çözüm noktasını temsil etmektedir. Her birey iki farklı formda temsil edilmektedir. Kromozom GA'nın kullandığ 1 bilgi, fenotip ise kromozomun model kuralları çerçevesinde özelliklerini tanımlar.

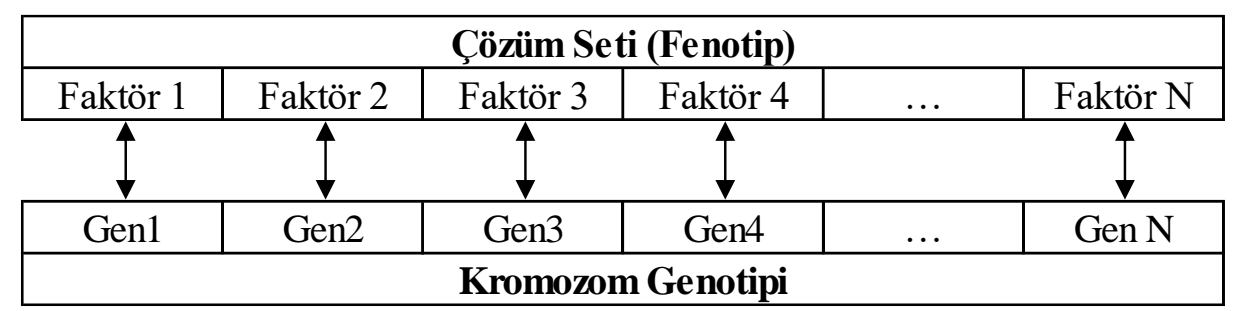

Şekil 1. GA Genotip ve Fenotip gösterimi

Şekil 2'de görüldüğü üzere kromozomlar genlerden oluşmaktadır. Modeldeki her bir faktör bir gene karşıllı gelmektedir.

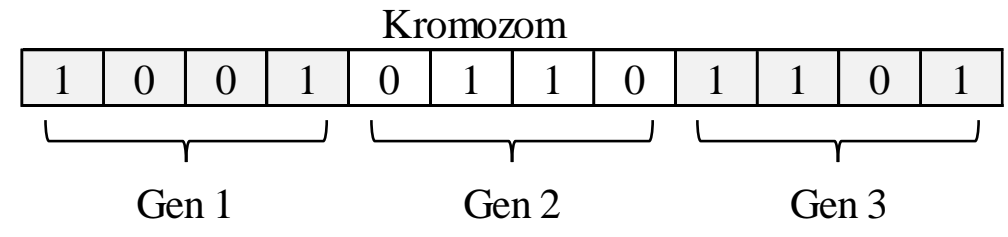

Şekil 2. Kromozom ve Gen Gösterimi 
Popülasyon: Fenotip parametreleri tanımlı belirli bir sayıda bireyin oluşturduğu topluluktur. GA'da popülasyonun iki önemli parametresi bulunmaktadır. Bunlar popülasyon nüfusu ve ilk oluşturulacak popülasyondur.

Veri Yapısı: GA'nın ana veri yapısını kromozomlar, fenotipler, amaç fonksiyonu ve fenotiplerin uygunluk değerleri oluşturmaktadır. Fenotip yapısı ile kromozomların ilişkisi modelde tasarlanan ilişki şemasına uygun olarak birbirine çevrilebilmektedir. Uygunluk değerleri ise algoritmanın amaç fonksiyonundan hesaplanmaktadır.

Arama Stratejisi: GA'da arama işlemi bir başlangıç popülasyonu oluşturulması ve algoritma durma koşulunu sağlayana kadar yeni bireylerin oluşturulması şeklinde ilerlemektedir. Arama işleminin global optimumu bulmak gibi birçok amacı olabilir ancak GA'nın çalışma mantığı ile bunu garantileyemez. Bir sonraki yaratılacak olan popülasyonda her zaman daha iyi bir birey bulunma ihtimali vardır. Bazı durumlarda ise algoritma yıllarca çalışsa bile ilk seferde bulunan çözümden daha iyi bir çözüm üretemeyecektir.

Kodlama: GA'da kodlama bireylerin modellenen fenotip kullanılarak genler şeklinde gösterimidir. Kodlama problem çözümüne göre farklı biçimlerde tercih edilebilir. Kromozomların kodlanması esnasında, üretilen kromozomların uygunluğu(feasibility) ve modelde tanımlanan şartları sağlayıp sağlamadığı kontrol edilmelidir. Bu yüzden İkili Kodlama (0-1), Sekizlik Düzende Kodlama (0-7), Permütasyon Kodlama ve Değer Kodlama gibi kodlama çeşitleri arasından kullanılacak algoritmaya uygun olanının bulunması gerekmektedir.

\begin{tabular}{|l|l|l|l|l|l|l|l|l|}
\hline Kromozom 1 & 8 & 6 & 4 & 2 & 1 & 3 & 5 & 7 \\
\hline Kromozom 2 & 1 & 2 & 3 & 4 & 5 & 6 & 7 & 8 \\
\hline
\end{tabular}

Şekil 3. Permutasyon Kodlama

Permutasyon kodlama sıralama problemleri için en uygun yöntemdir (Borovska, 2006, s. 2). $\mathrm{Bu}$ yüzden çizelgeleme problemlerinde permutasyon kodlama kullanılmaktadır.

Doğal Seçim İşlemi: GA' da yeni bir bireyin yaratılması amacıyla ebeveynlerinin belirlenmesi işlemine seçim demir. Kodlama tipine karar verdikten sonra seçim işleminin ne şekilde yapılacağına karar verilmelidir. Seçim işleminin sonunda bir önceki nesille kıyaslandığında daha yüksek uygunluk değerine sahip bireyler oluşması beklenmektedir.

Popülasyon içerisinden yeni bireylerin oluşturulması için seçim kromozomların uygunluk değerleri dikkate alınarak yapılmaktadır. Darvin'in evrim teorisine göre en başarılı bireyler yeni nesli oluşturmak için hayatta kalmaktadır. GA'da yeni popülasyon oluşturulurken daha başarılı bireylerin seçimi daha başarılı bireylerin oluşumunu hızlandıracaktır ancak daha iyi bireyleri kullanma oranı arttıkça algoritmanın lokal optimumlara takılma olasılığı da artacaktır. Aynı şekilde başarılı bireylerin yeterli yoğunlukta kullanılmaması durumunda da evrim görece daha yavaş ilerleyecektir. Bu sebeple seçim işlemi çaprazlama ve mutasyon işlemleri ile dengelenmelidir. GA'da Rulet Tekeri, Rastgele, Turnuva, Eşik Değer, Değer Sıralamalı ve Seçkinlik (Elitizm) gibi farklı seçim metotları kullanılmaktadır.

Çaprazlama (Crossover): Çaprazlama işlemi, popülasyon içerisinden seçilen iki bireyin yeni bireyler oluşturulması için kullanılması işlemidir. GA'da eşleştirme havuzunu kullanarak daha iyi bireyler yaratılması amacıyla çaprazlama işlemi kullanılmaktadır. Temel çaprazlama işlemi üç adımdan oluşmaktadır: (1) Popülasyon içerisinden belirlenen yöntem ile iki ebeveyn 
seçilmesi, (2) Ebeveynlere ait kromozomlar üzerinden çaprazlama noktası belirlenmesi, (3) Belirlenen çaprazlama noktası kullanılarak iki kromozomun parçalarının karşılıklı değiştirilmesi.

Çaprazlama işleminin hangi sıklıkla yapılması gerektiği GA'da çaprazlama olasılığ parametresi (Pc) olarak tanımlanması gerekmektedir. Bu olasılık \%0 olduğunda tüm ebeveynler çaprazlamaya tabi tutulmadan bir sonraki nesle aktarılırken \%100 olması durumunda tüm ebeveynler yeni neslin oluşturulması için çaprazlama işlemine tabi tutulacaktır.

Mutasyon (Mutation): GA'da bulunan ikinci operatör mutasyon operatörüdür. Mutasyon işlemi GA'da nesiller arası kaybolan genetik materyalin tekrardan elde edilebilmesine yardımcı olan bir mekanizmadır. Bu mekanizma ile GA'nın lokal optimuma takılma olasılığ düşürülerek çözüm uzayına ait daha geniş bir alanın taranması sağlanır. Mutasyon işlemi farklı şekillerde gerçekleştirilebilmektedir. Gen ve Cheng (2000) mutasyon operatörünün bazen çaprazlamadan daha önemli bir rol oynayabileceğini kanıtlamıştır. Dolayısıyla çaprazlama ve mutasyon operatörlerinin eldeki probleme göre iyi tasarlanmış olmaları gerekmektedir.

Mutasyon olasılığı (Pm) bireylerin hangi olasılıkla mutasyona uğrayacağını tarifleyen GA parametresidir. Mutasyon olasılığının \%0 olması hiçbir bireyin mutasyona uğramayacağını tariflerken \%100 olması tüm bireyler üzerinde mutasyon gerçekleşeceğini belirtmektedir. Yüksek mutasyon oranları tercih edilmez çünkü mutasyon oranının yükselmesi GA'nın rastgele arama yapan bir algoritmaya dönmesine yol açacaktır. Hamilton ve Ridley (2005) GA “da mutasyon oranının doğada olduğu gibi genellikle oldukça düşük olduğunu belirtmektedir. Kocamaz ve Çiçekli (2010) mutasyon oranın etkinliği üzerine yaptıkları çalışmada, permütasyon tipi kodlamalarda mutasyon oranın \%5-\%9 oranları arasında iyi sonuçlar verdiğini belirtmektedir.

Yenileme (Replacement): Seçim işlemi sonrası seçilen iki bireylerden yeni iki birey türetilmektedir ancak bu bireylerin hepsi popülasyona geri dönememektedir. Yenileme GA'da ebeveynler ve ebeveyn birleşmesi sonucu oluşan çocuklardan hangilerinin popülasyona dahil edileceği kararıdır. GA'da seçim ve çaprazlama işlemleri sonrası popülasyon sayısı sabit olacağı için hangi bireylerin popülasyona dönmesi gerektiği tanımlanmalıdır. Bu işlem rastgele yenileme, zayıf birey eliminasyonu, yeni nesil aktarımı olmak üzere birkaç farklı yöntem ile yapılabilmektedir.

Aramanın Sonlandırılması: GA sonlandırma koşulu farklı alternatifler ile oluşturulabilmektedir. Bunlar;

- İterasyon sayısının belirlenerek kaç nesil boyunca tarama yapılacağının tanimlanmasiyla,

- GA'nın çalıştırılacağı zamanın tanımlanmasıyla,

- Son çalıştırılan iterasyonda amaç fonksiyonunda herhangi bir iyileşme sağlanamadiğında,

- Belirlenen nesil sayısı kadar iterasyonda amaç fonksiyonunda herhangi bir iyileşme olmamasi durumunda,

- Belirlenen süre içerisinde amaç fonksiyonunda herhangi bir iyileşme olmaması durumunda, 
- En iyi bireye ait uygunluk değerinin belirlenen değerin üzerine çıkması durumunda,

- En kötü bireye ait uygunluk değerinin belirlenen değerin üzerine çıkması durumunda,

- Toplam uygunluk değerinin belirlenen değerin üzerinde çıkması durumunda.

\section{Uygulamanın Yapıldığı Üretim Tesisi}

Çalışmanın yapıldığı üretim tesisi pazar koşullarının getirdiği rekabetçiliğe cevap verebilmek için birbirinden farklı birçok ürün üretebilme yeteneğine sahiptir. Mevcut makine parkının kapasitesi ve yetenekleri doğrultusunda; farklı standartlar kullanarak, geniş özellik varyasyonları ve özel hammadde grupları ile üretim yapabilmektedir. Tesiste üretim FIFO mantığı ile yapılmakta olup tesis istasyonları arası yarı mamullerin transferi için otomasyonlu bir taşıma sistemine sahiptir.

\section{Üretim Akışı}

Üretim akışı üretilen ürünün parametreleri, özel hammadde kaliteleri, üretim standardına ve satın alınan hammaddenin ek özelliklerine göre farklılık göstermektedir. Bu farklılık kullanılan makinalarda yapılacak ayarların değişikliği olabileceği gibi akışın farklı makinalar üzerinden gerçekleşmesine de neden olabilmektedir.

Üretim akışı ayrıca üretim yapan tesiste bulunan ekipmanlara göre de şekillenebilmekte, sıralama olarak belli adımlar önce veya sonra olabilmektedir. Üretim akışı üzerindeki bir başka etmen ise üretim standartları üzerine müşterilerin talepleri doğrultusunda eklenen kalite kontrol/test adımlarıdır. Üretim prosesini tüm adımları ile bakıldığında 18 temel adımdan oluşmaktadır. Bu adımlar ürün tipi, kullanılan hammadde tipi , üretim standardına ve satın alınan hammaddenin ek özelliklerine göre farklılık göstermektedir. Şekil 4'te Temsili Üretim Akışı gösterilmektedir. 


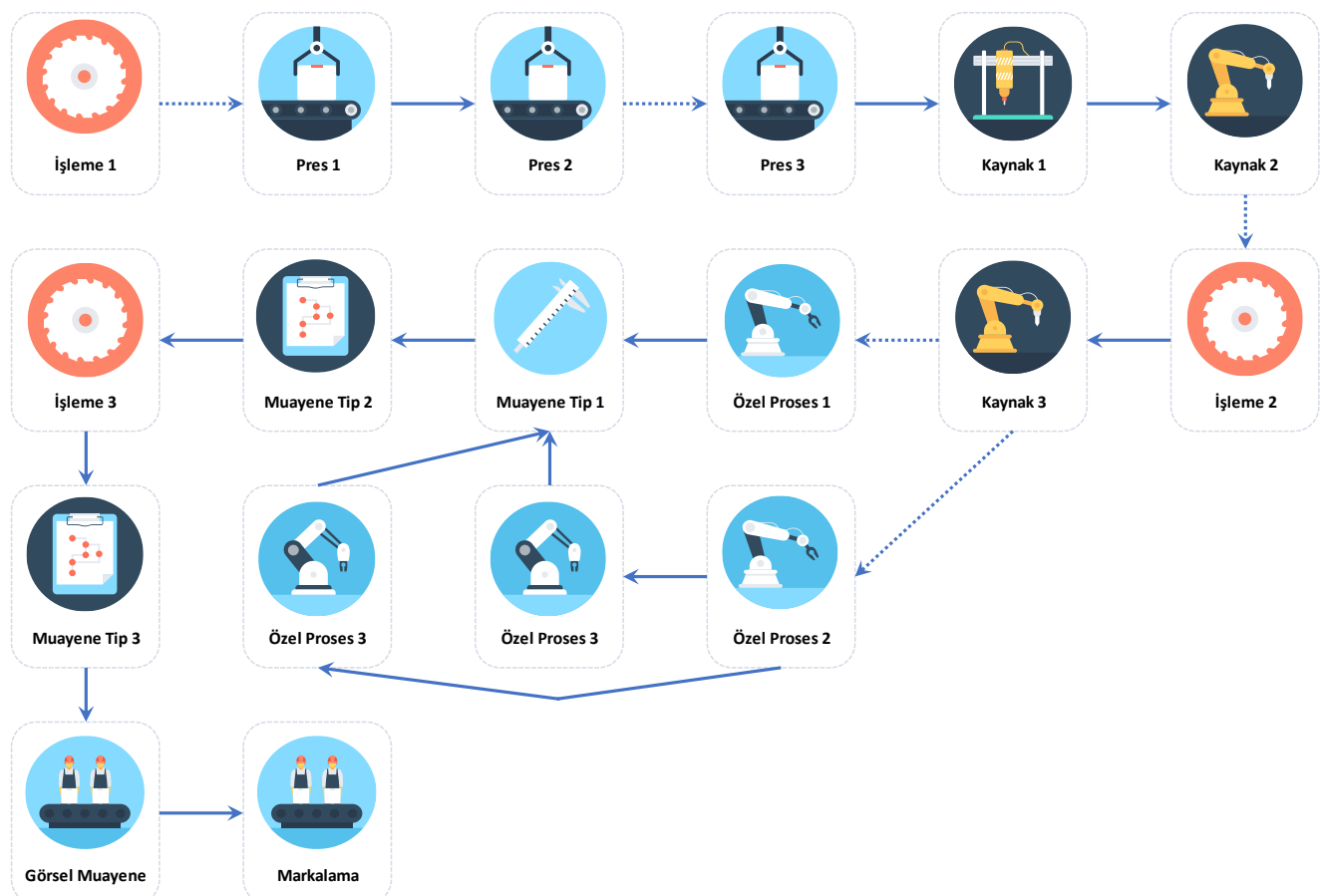

Şekil 4. Üretim Akış1

Üretim tesisi 18 farklı operasyon gerçekleştirebilecek 19 istasyon ve istasyonlar arası taşıma sisteminden oluşmaktadır. Üretim akışı FIFO kuralına göre gerçekleşmektedir. İstasyonlar arası konveyörler belirli sayıda yarı mamul depolama kapasitesine sahiptir. Konveyörler kapasiteleri kadar yarı mamul ile bekler konuma geçtiklerinde bu konveyöre yarı mamul iletecek olan istasyonların tamamladıkları yarı mamulü konveyör üstüne iletememelerine ve bu sebeple durmasına sebep olur. Özel Proses 1 istasyonunda iki adet yükleme arabası mevcuttur. Operasyon tipine bağlı olarak bir grup malzemede bu iki araba sirayla kullanılabilirken bazılarında ise sadece bir araba kullanılabilmektedir.

\section{4. Üretim Sisteminin Tanımlanması ve Modellenmesi}

Çizelgeleme optimizasyonu problemini daha basite indirgemek adına çözüm aşaması iki adıma bölünmüştür.

Birinci adımda üretim hattı Rockwell Arena 14.0 programı kullanılarak, üretimi yapılabilecek tüm ürünler dikkate alınarak modellenmiş, bu model Visual Studio C\# ile hazırlanan hesaplama modelinin doğruluğunun kontrol edilmesi için kullanılmıştır.

İkinci adımda ise Visual Studio C\# ile hazırlanan hesaplama modelinin tek bir kaynak olduğu varsayılarak tek makine çizelgeleme için GA optimizasyon modeli kurulmuştur.

\section{Üretim Sisteminin Modellenmesi ve Kabuller}

Üretim çizelgeleme probleminin tanımlanması için üretim hattının modellenerek hattın işleyişi Rockwell Arena 14.0 programı kullanılarak simülasyon modeline yansıtılmıştır. Simülasyon modeli esnek olması ve farklı model karmalarının da simüle edilmesinde 
kullanılması amaçlanarak MS Excel entegrasyonu ile hazırlanmış, modelde kullanılacak tüm veriler parametrik hale getirilmiştir.

Model en fazla 3 farklı tip arka arkaya simüle edilebilecek şekilde oluşturulmuştur ve tipler bazlı girilmesi gereken ürün bilgileri Tablo-1'de belirtilmiştir. İşletmenin bilgi gizliliği nedeniyle parametre değerleri temsili olarak verilmektedir.

Tablo 1. Simülasyon Rota Parametreleri (Temsili)

\begin{tabular}{lccc}
\hline Model Parametreleri & Tip1 & Tip2 & Tip3 \\
\hline Üretilecek Adet & 50 & 100 & 75 \\
Ürün Parametresi (1) & P0-1 & P0-2 & P0-3 \\
Ürün Parametresi (2) & P1-1 & P1-1 & P1-2 \\
Pres 1 / Pres 3 uygulaması & 2 & 2 & 2 \\
İşleme 2 Operasyonu & 1 & 0 & 1 \\
Özel Proses Tipi (1/2) & 1 & 1 & 1 \\
Özel Proses Tipi (3/4) & 1 & 1 & 1 \\
Özel Test İhtiyacı & 0 & 0 & 0 \\
Lot Numaras1 & 1 & 2 & 3 \\
İşleme 1 Parametresi & 1 & 2 & 3 \\
Muayene Tip1 İhtiyacı & 0 & 1 & 0 \\
İşleme 3 Parametresi & 0 & 1 & 0 \\
Muayene Tip2 İhtiyacı & 1 & 0 & 0 \\
Muayene Tip3 İhtiyacı & 1 & 0 & 0 \\
\hline
\end{tabular}

Tablodaki parametreler sirasıyla;

- Üretilecek Adet: İlgili tipten kaç adet üretime alınacağını belirtmektedir

- Ürün Parametresi (1): Ürün dış ebatlarını temsil etmektedir

- Ürün Parametresi (2): Ürünün malzeme kalınlığını belirtmektedir

- Pres 1 / Pres 3 uygulaması : İlgili tipin ürün rotasında hangi operasyondan geçeceğini belirtmektedir. ((1) Pres 1 Operasyonu/ (2) Pres 3 Operasyonu)

- İşleme 2 Operasyonu : İlgili tipin ürün rotasında İşleme 2 operasyonu gereksinimi olup olmadığını belirtmektedir. (0-Yok / 1-Var)

- Özel Proses Tipi (1/2): İlgili tipin Özel Proses (1/2) Tipini belirtmektedir (1- Özel Proses 1 / 2- Özel Proses 2 / 3-Yok)

- Özel Proses Tipi (3/4): İlgili tipin ürün rotasında hangi operasyondan geçeceğini belirtmektedir. (1 - Özel Proses 3/ 2- Özel Proses 4)

- Özel Test İhtiyacı (n): İlgili tipin üretim standardından gelen numune alma sıklığını belirtmektedir (1 Numune / $\mathrm{n}$ adet) 
- Lot Numarası: Tiplerin birlikte Özel Proses 1'e girebilme koşullarını belirtmektedir. Lot numarası aynı olan ürünler birlikte Özel Proses 1'de işleme girebilmektedir.

- İşleme 3 Parametresi: İlgili tiplerin İşleme 3 operasyonunda işlenecek olan işleme parametresini belirtmektedir.

- Muayene Tip1 İhtiyacı: İlgili tiplerin Muayene Tip1'e tabi tutulup tutulmayacağını belirtmektedir. ((1) Test yapılacak / (0) Test yapılmayacak)

- Muayene Tip2/3 İhtiyacı: İlgili tipin ürün rotasının hangi adımlarından sonra Muayene Tip2/3 ‘e tabi tutulacağını belirtmektedir.

Model çalıştırıldığında FILE bloğu model parametrelerini okuyarak Tip bazlı kayıt setlerine dönüştürmektedir. Model en fazla 3 farklı tipi sırayla simüle edebilecek şekilde hazırlanmış olup ürünlerin imalata giriş sırası Tip1, Tip2, Tip3 olacak şekilde modelleme gerçekleştirilmiştir.

Simülasyon saati başlatılmadan önce CREATE blokları ile yaratılan farklı tipler için ASSIGN blokları yardımıyla her tipe ait rota parametreleri ürünlerin üzerine ATTRIBUTE olarak yazılmaktadır. Bu parametreler yardımı ile modelin tüm operasyonlarında Üretim Sistemi Kısıtlarında belirtilen kalıp değişimleri, ürünlerin operasyonlar arası izleyeceği rotalar belirlenmektedir. Tüm ENTITY'ler gerekli parametreleri aldıktan sonra Plan isimli bir QUEUE modülünde biriktirilerek ilk operasyonla birlikte sisteme girişleri sağlanır.

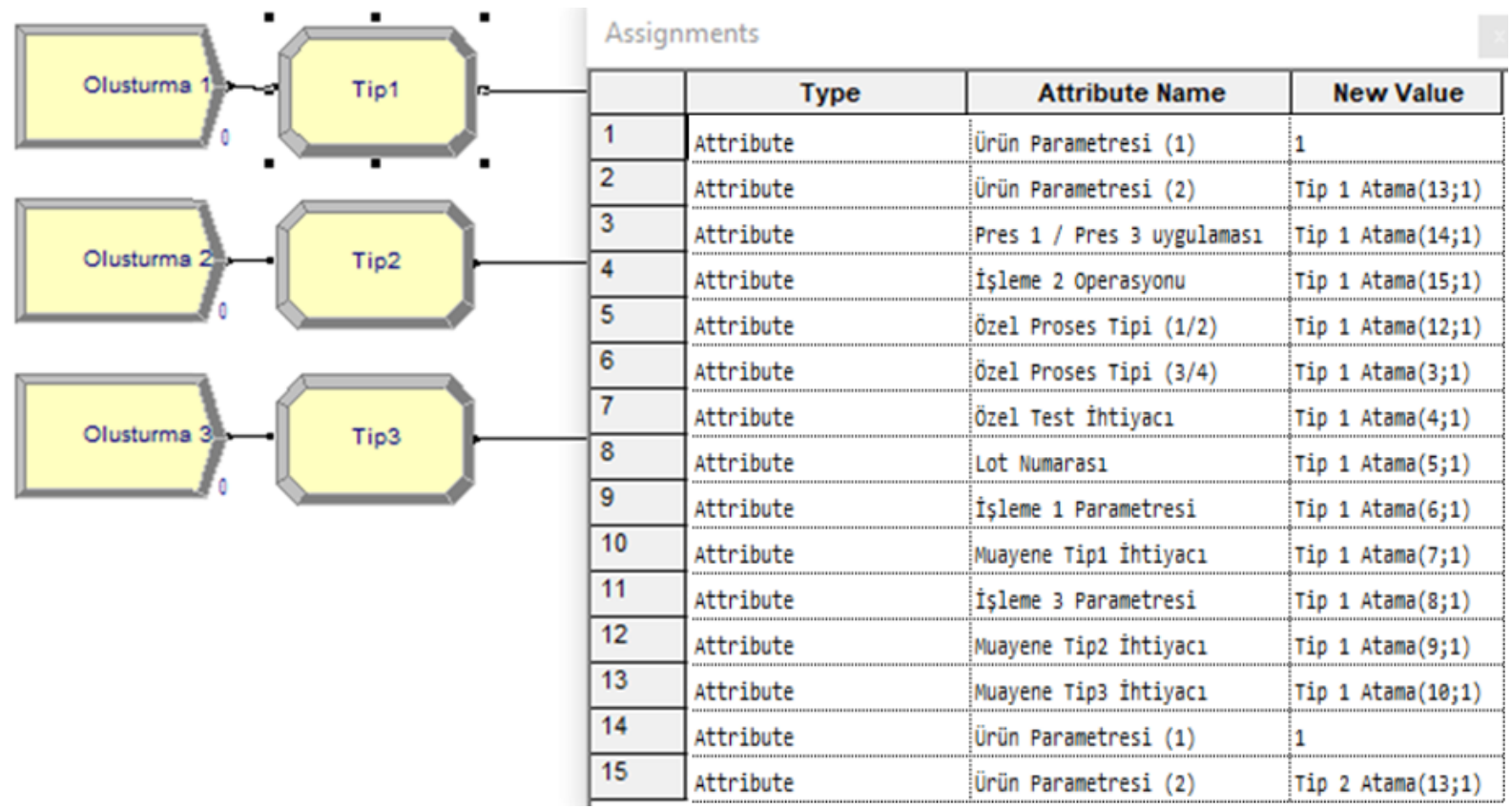

Şekil 5. CREATE ve ASSIGN Blokları

Tüm proseslerin önünde prosesler arasında taşıma görevi yapan konveyörlerin kapasiteleri kadar ürün kapasitesine sahip QUEUE modülleri mevcuttur. Tüm süreçler alt modeller olarak ayrı ayrı modellenmiştir. Alt sürecin başlangıcında ilgili proseste kaynak olarak kullanılan makine SEIZE modülü ile doldurulmaktadır, sonrasında DECIDE modülü ile her yeni gelen yarı mamul için bir önceki yarı mamulün ilgili süreçte ayar/kalıp değişimi gerektirecek parametreleri karşılaştırılarak eğer bir kalıp değişimi işlemi gerekiyorsa FALSE yolu izlenerek önce yeni makine parametreleri ASSIGN modülü kullanılarak ilgili kaynağa yazılır ardından Tablo2'de proses için belirtilen ayar/kalıp değişimi süresi kadar DELAY modülü ile gecikme 
sağlanarak ikinci DECIDE modülüne geçilir. Eğer kalıp değişimi gerekmiyor ise TRUE yolu izlenerek ikinci DECIDE modülüne geçilir. İkinci DECIDE modülü işlemdeki yarı mamulün tipine göre yarı mamulü kendine ait operasyon süresinin bulunduğu DELAY modülüne yönlendirmektedir. Operasyon sonrası yarı mamulün hangi istasyona gideceğine karar veren DECIDE modülü bulunmaktadır. Bu modül yarı mamul üzerindeki rota bilgilerini kullanarak bir sonraki istasyonun hangisi olduğunu belirleyerek yarı mamulü ilgili rotaya sevk etmektedir. RELEASE modülleri öncesinde bulunan DECIDE modülleri bir sonraki istasyonun kuyruk kapasitesini her 0,1 dakikada bir kez kontrol ederek eğer yarı mamulün gideceği kuyruk doluysa makinanın yeni bir yarı mamul almasına izin vermemektedir. Eğer yarı mamulün gönderileceği kuyruk müsait ise RELEASE modülü ile makineyi boşaltarak yeni bir yarı mamul almasına izin vermektedir.

Modelde kısıtlar karşısında yapılan kabuller;

- Kaynak operasyonlarında ayarların sadece Ürün Parametresi(1) değişiminden etkilendiği varsayılmıştır.

- Modeldeki tüm kuyrukların FIFO yöntemiyle çalışacağı kabulü yapılmıştır.

- Özel Proses Tipi (1) kapasitesinin Ürün Parametresi(1)'den etkilenmediği ve yedi ürün olduğu kabulü yapılmıştır.

- Özel Proses Tipi (1)'in bir önceki işlem tamamlandıktan sonra tekrar yedi adet ürün yüklenmesi veya bir önceki işlemin tamamlanmasından iki saat bekledikten sonra içindeki ürünler ile yeni işleme başlayacağı kabulü yapılmıştır.

- İmalat koşullarında ortaya çıkabilecek tamir ve hurda ürünlerin oluşma olasılı̆̆g ihmal edilmiştir.

- İstasyonlar arası yarı mamul transfer süreleri ihmal edilmiştir.

- Modelde tip sıralaması önceden belirlendiği için kalıp değişim süreleri ürün sıralamasına göre değişkenlik gösteren makinalar için kalıp değişim/ayar sürelerinin sıralamaya uygun olarak verileceği varsayılmıştır.

- Muayene Tip2/3 operasyonları rotasında Muayene Tip2 adımı bulunan bütün ürünlerin hem Muayene Tip2 hem de Muayene Tip3 operasyonlarına uğrayacakları kabulü ile modellenmiştir.

\section{Genetik Algoritma ile Optimizasyon Modeli Kurulması}

GA modeli kurulurken genetik algoritma yapısının belirlenmesi ve uygunluk fonksiyonunu hesaplayan bir üretim hattı modellemesi yapılmıştır.

\section{GA Yapısının Oluşturulması}

Çizelgeleme optimizasyonu problemi için her ürün kendine ait tekil bir numara ile temsil edilecek şekilde permutasyon kodlama yöntemi kullanılarak üretim planları popülasyondaki bireyler olarak kodlanmıştır. Bu kodlamada her gen bir ürüne denk gelmektedir. Bu tekil ürün numarası ile ürüne ait;

- Tip Tanımı: Farklı Ürün Parametreleri ile Tekilleştirilmiş Ürün 
- Ürün Tipi Temsili Tutarı

- Ürün Tutarı Üzerinden Uygulanacak Gecikme Cezası

- Ürünün İzleyeceği Makina Rotası

- Ürünün Makinalardaki Temsili Operasyon Süreleri

bilgilerine erişilebilecek şekilde fenotip kodlaması C\# ile hazırlanan programda gerçekleştirilmiştir. Yeni oluşturulacak bireylerin ebeveynlerinin seçimi işlemimde rulet teker yöntemi kullanılmıştır.

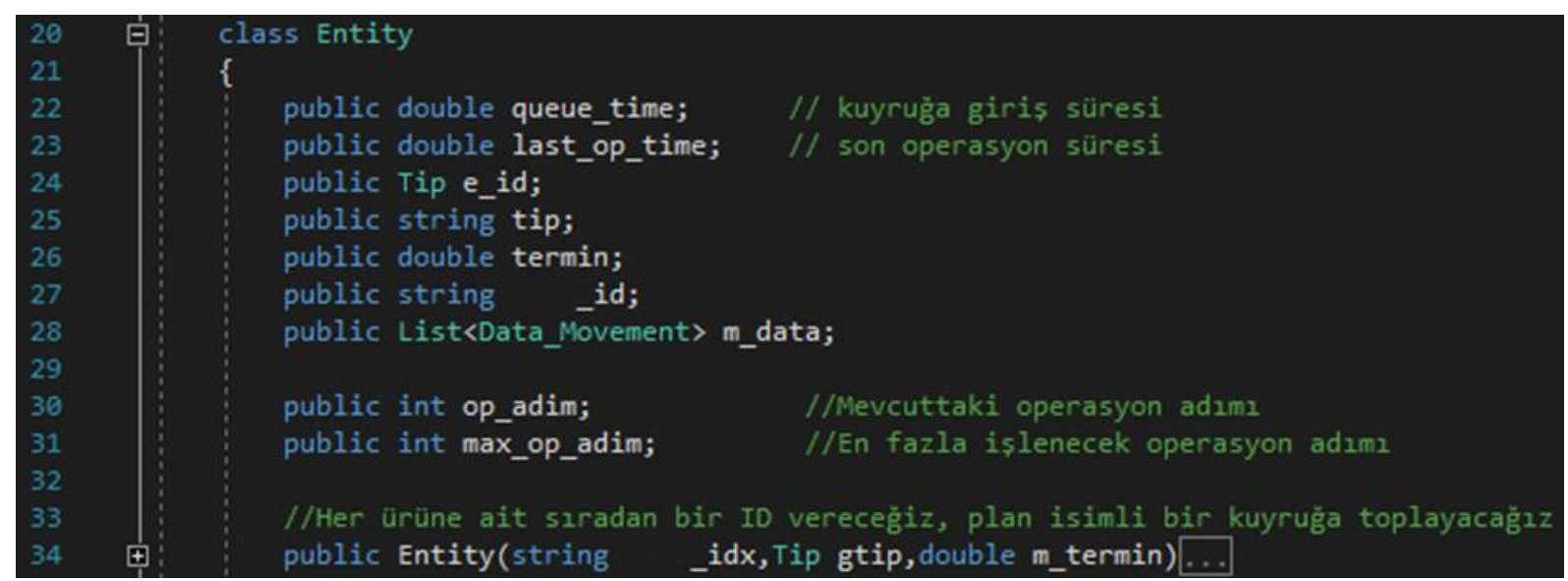

Şekil 6. GA- Uygulama Fenotip Kodlaması

Kromozom kodlama yöntemi olarak permutasyon kodlama kullanıldığı için çaprazlama operatörü tek ve iki noktalı opsiyonlar seçilebilir olarak, sıralı çaprazlama yöntemi ile kodlanmıştır. Program arayüzü yardımı ile çaprazlama operatörünün tipi değiştirilebilmektedir. Mutasyon operatörü permutasyon kodlama ile birlikte gen içerisinde iki rastgele noktanın yer değiştirmesi şeklinde kodlanmıştır. Seçkinlik fonksiyonu kullanıcının seçimine bağlı olarak program arayüzü yardımı ile tanımlanabilir şekilde en fazla 10 birey kapasiteli olarak tanımlanabilmektedir.

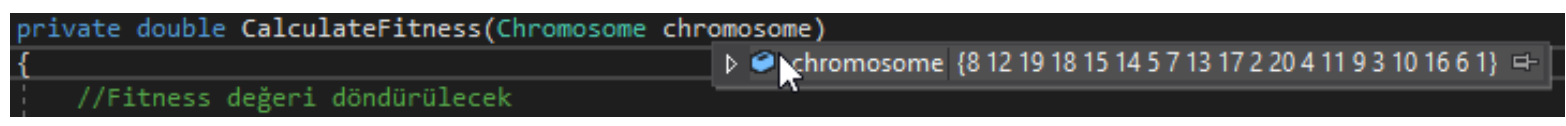

Şekil 7. GA Kromozom Kodlaması

Problemlerde dinamik denemeler yapabilmek, GA parametrelerini deneyerek daha uygun çözümler bulabilmek için program ara yüzünden çaprazlama, mutasyon oranı, iterasyon sayısı ve popülasyon nüfusu tanımlanabilecek şekilde program arayüzü tasarlanmıştır.

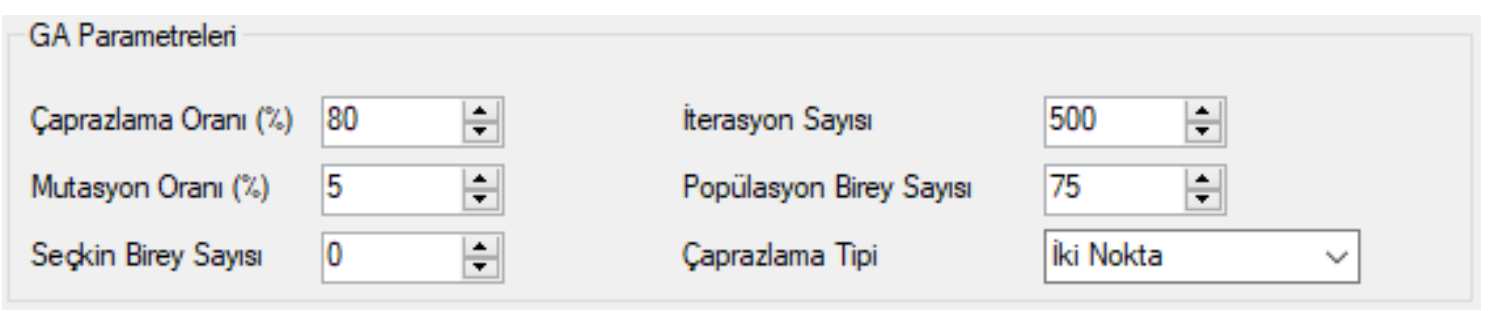

Şekil 8. GA Çizelgeleme Optimizasyonu- Parametreler

Yeni nesil oluşturulmasında çaprazlama işlemi sonucu oluşan bireylerin bir sonraki nesle aktarımı için sadece yeni bireyler popülasyona döndürülmektedir. Çaprazlama oranının görece yüksek tutulduğu çözüm denemelerinde çözüm uzayının daha geniş bir bölgesinde 
tarama yapabilmek için ebeveyn ve yeni bireylerden en iyi bireylerin popülasyona döndürülmesi alternatifi tercih edilmemiştir.

\section{Amaç Fonksiyonu Belirlenmesi}

GA için amaç fonksiyonu tanımlanırken ilgili sektöre ait özel durumlar göz önünde bulundurulmuştur. Ağır sanayi sınıfa giren firmaların, diğer firmalarda olduğu gibi, ekipman verimliliğini olabilecek en yüksek seviyede tutarak üretim faaliyetlerini gerçekleştirmeleri gerekmektedir.

Proje ve İnşaat alanında faaliyet gösteren firmaların aldıkları siparişlerin büyük bölümünde ürün bedeli üzerinden hesaplanan ağır gecikme cezaları bulunmaktadır. Bu cezalar gecikme günü bazlı üst bir sınıra kadar hesaplanabildiği gibi gecikme durumunda sabit ödenecek tutarlar da olabilmektedir.

GA Amaç fonksiyonu tasarlanması esnasında bu iki kısıt göz önüne alınarak minimum maliyeti elde etmek amaçlanmıştır. Amaç fonksiyonunun ilk bölümünde üretimin çalışma maliyeti;

$$
\begin{aligned}
& S M_{f}=\text { Fabrikanın saatlik çalışma maliyeti } \\
& S_{c}=\text { Çalışma Saati }
\end{aligned}
$$

olmak üzere $\left(S M_{f} \times S_{c}\right)$ olarak hesaplanmaktadır. Amaç fonksiyonun ikinci bölümünde ise geç teslim sebebiyle kaybedilecek kazancı maliyet olarak kabul ederek;

$$
\begin{aligned}
& O_{g}=\text { Ürün Gecikme Bedeli (\%) } \\
& U T_{g}=\text { Geciken Ürün Tutarı }
\end{aligned}
$$

olmak üzere gecikme maliyeti ;

$$
\sum_{i=1}^{n}\left(O_{g i} \times U T_{g i}\right)
$$

olarak tüm geciken ürünlerin gecikme cezası oranları ile ürün tutarlarının çarpımları toplamı ifade edilebilmektedir.

$$
T M=\text { Toplam Üretim Maliyeti }
$$

olmak üzere amaç fonksiyonumuz;

$$
\operatorname{Min}(T M)=\left(S M_{f} \times S_{c}\right)+\sum_{i=1}^{n}\left(O_{g i} \times U T_{g i}\right)
$$

olarak ifade edilebilmektedir. Bu amaç fonksiyonu ile toplam üretim süresinin kısa olmasının yanısıra gecikme maliyetlerini de dikkate alarak ürünlerin gecikme yaşamayacağı noktalara planlanması amaçlanmıştır.

Amaç fonksiyonunda gerçekleştirilen imalatın toplam şirket maliyeti göz önünde bulundurulduğu için gecikme yaşayan parçalara ilişkin oluşan maliyetlere herhangi bir ağırlıklandırılma yapılmamıştır. Ancak bir ay veya daha uzun dönemli planlama optimizasyonu problemlerinin değerlendirilmesi durumunda ürünlerin ceza bedelleri toplam maliyetle kıyaslandığında küçük bir tutar olarak gerçekleşeceği için uzun dönemli problemler ele alınırken gecikmelerin önemli olduğu durumlarda amaç fonksiyonunun gecikmeleri dikkate alabilmesi parametrik girilebilen ceza puanlarının daha yüksek girilmesi gerekecektir. 


\section{Amaç Fonksiyonu İçin Model Oluşturulması ve Doğrulanması}

Amaç fonksiyonunun hesaplanabilmesi için kurulan simülasyon modeline paralel hesaplama yapan bir model C\# ile geliştirilmiştir. Model içerisinde ürünler GA'da kullanılan kodlamaya uygun olarak kromozom içindeki genlerde tutulan tekil ürün numarası bilgisi ile ifade edilmektedir. Bu numara ile temsil edilen ürün kendi içerisinde tip, rota, operasyon süreleri, üretim içerisindeki durumu ve hareket dökümü bilgileri her ürüne özel tutulacak şekilde model hazırlanmıştır.

Tüm makinalar iş istasyonu tanımlarında bulunan makina ismi ile temsil edilmektedir. $\mathrm{Bu}$ makina ismi ile makinanın mevcut çalışma parametreleri, yeni gelen ürün tipine göre ayar gereksinimini kontrol eden bir mekanizma, ayar gereksinimi durumunda olası ürünlerin birbirleri arasındaki değişimlerini tutan bir zaman matrisi, makina önünde bekleyen ürünlerin depolanabilmesi için kapasite kısıtlı bir kuyruk modeli ve hareket dökümü kodlanarak makina üzerine yüklenmektedir.

Üretim Sisteminin Modellenmesi ve Kabuller bölümünde tanımlanan tüm kısıtlar modele yansıtılmıştır. C\# ile hazırlanan model ile Arena modeli, tek ürün ve iki ürün arası model geçişi durumları hesaplanarak modellerin paralel çalışması test edilmiştir. Her iki model de aynı veri setleri ile hesaplama yaparken aynı sonuç elde edilmiştir.

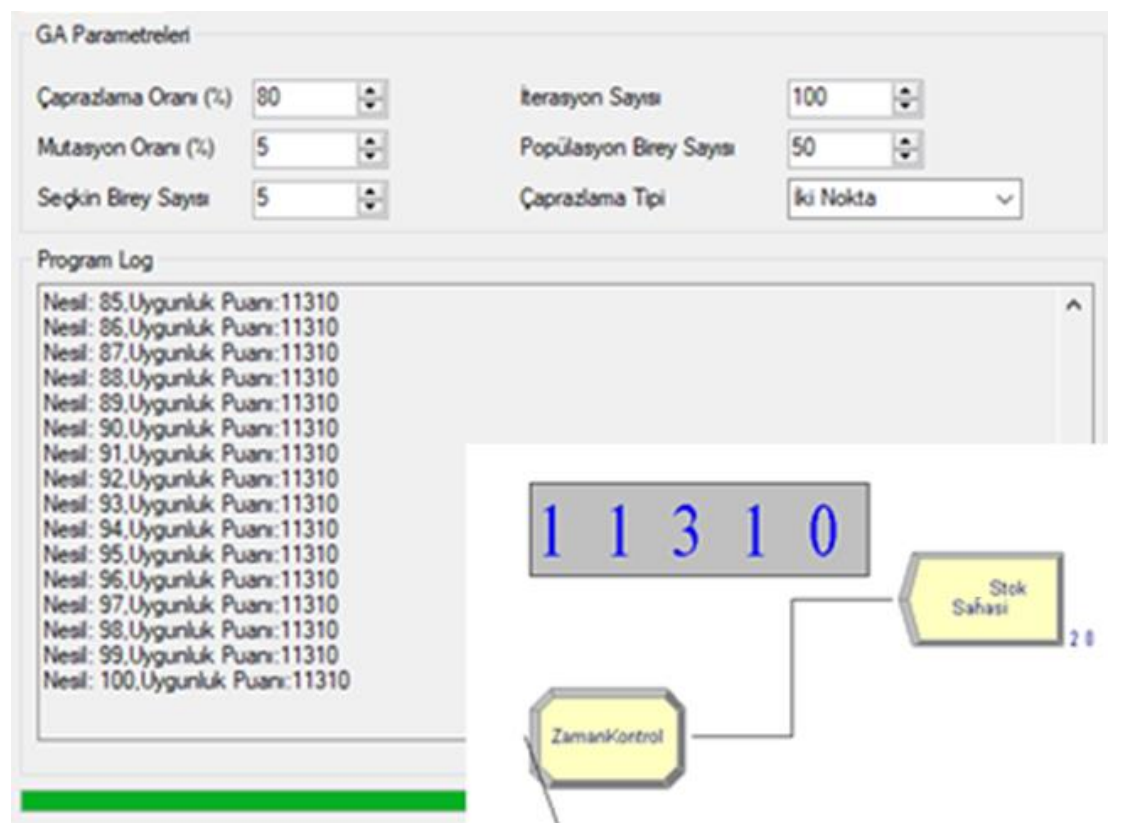

Şekil 9. GA ve Arena Model Karşılaştırması - İki Model

\section{GA için Kullanılan Veri Seti}

Tablo 3'te temsili makina ismi, tanımlanan 4 farklı parametreden hangileri değiştiğinde makinada ayar / tip dönüşü gerçekleşeceği ve makinaların arkasında bulunan ara stok alanlarının kaç ürün alabildiği tanımlanmaktadır. Herhangi bir parametre değerinin "1" olması bu makinanın ürünün bu özelliği değiştiğinde ayar ihtiyacı olacağını belirtmektedir. Üretim hattındaki 18 makina için bu tanımlar hazırlanmıştır. 
Tablo 3. Makina Bilgileri

\begin{tabular}{|c|c|c|c|c|c|c|}
\hline 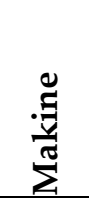 & 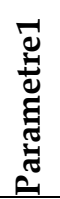 & 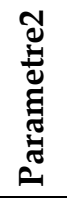 & 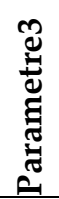 & 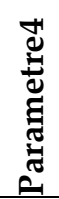 & 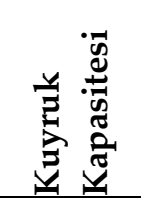 & Makine tanımı \\
\hline M1 & 0 & 0 & 0 & 1 & 100000 & İşleme 1 İstasyonu \\
\hline M2 & 1 & 1 & 1 & 0 & 5 & Pres 2 İstasyonu \\
\hline M3 & 1 & 1 & 0 & 0 & 5 & Pres 1 İstasyonu \\
\hline M4 & 0 & 1 & 1 & 0 & 5 & Kaynak 1 İstasyonu \\
\hline M5 & 0 & 1 & 1 & 0 & 5 & Kaynak 2 İstasyonu \\
\hline M6 & 0 & 1 & 1 & 0 & 5 & İşleme 2 İstasyonu (Opsiyonel) \\
\hline M7 & 0 & 1 & 1 & 1 & 5 & Kaynak 3 İstasyonu \\
\hline M8 & 0 & 0 & 0 & 0 & 20 & Özel Proses 1 İstasyonu (Opsiyonel) \\
\hline M9 & 1 & 0 & 0 & 0 & 3 & Özel Proses 2 İstasyonu (Opsiyonel) \\
\hline M10 & 1 & 0 & 0 & 0 & 3 & Özel Proses 3 İstasyonu (Opsiyonel) \\
\hline M11 & 1 & 0 & 0 & 0 & 3 & Özel Proses 4 İstasyonu (Opsiyonel) \\
\hline M12 & 1 & 0 & 0 & 0 & 3 & Muayene Tip 1 İstasyonu \\
\hline M13 & 1 & 0 & 0 & 0 & 5 & Muayene Tip 2 İstasyonu \\
\hline M14 & 0 & 0 & 1 & 0 & 5 & Pres 3 İstasyonu \\
\hline M15 & 1 & 0 & 1 & 0 & 5 & İşleme 3 İstasyonu \\
\hline M16 & 1 & 0 & 0 & 0 & 5 & Muayene Tip 3 İstasyonu \\
\hline M17 & 0 & 0 & 0 & 0 & 5 & Görsel Muayene İstasyonu \\
\hline M18 & 0 & 0 & 0 & 0 & 5 & Markalama İstasyonu \\
\hline
\end{tabular}

Tanımlanan üretim hattında üretilebilecek ürünler "Urunler" bölümünde ürün tipleri, bu tiplere ait makina tanımında kullanılan tip değişim parametrelerinin tanımlandığ sütunları ve ürün gecikmesi durumunda ceza hesaplanabilmesi için ürün tutarı ve ceza (\%) puanları bulunmaktadır. Ele alınan problemde toplamda 20 farklı tip tanımlanmıştır. Tanımlanan tiplere ait örnek veriler Tablo 4'te görülmektedir.

Tablo 4. Ürün Tanımlama Bilgileri

\begin{tabular}{ccccccc}
\hline \multirow{2}{*}{ Tip } & \multicolumn{3}{c}{ Parametreler } & \multicolumn{2}{c}{ Diğer Veriler } \\
& Par1 & Par2 & Par3 & Par4 & Ürün Tutar1 & Gecikme Cezas1 \#/100 \\
\hline Tip1 & P0-1 & P1-2 & P2-1 & P3-4 & 1000 & 0.05 \\
Tip2 & P0-1 & P1-2 & P2-1 & P3-4 & 1000 & 0.05 \\
Tip3 & P0-2 & P1-1 & P2-1 & P3-3 & 1000 & 0.05 \\
Tip4 & P0-2 & P1-1 & P2-1 & P3-3 & 1000 & 0.05 \\
Tip5 & P0-2 & P1-1 & P2-1 & P3-3 & 1000 & 0.05
\end{tabular}


Tanımlanan makinalar ve ürünler dikkate alınarak, 18 makinanın her biri için tanımlanan 20 farklı tipe ait ürünlerin üretim tesisi içerisinde izleyeceği rotalar, bu rotalardaki istasyonlarda yapılacak operasyonlara ait operasyon süreleri tüm makinalar için Süreler bölümünde tanımlanmıştır. Tablo 5 'te de görüldüğü gibi, operasyon sıralaması ilk operasyon en solda olacak şekilde birbirini izleyen operasyonlar eklenerek hazırlanmıştır.

Tablo 5. Ürün İstasyon Rota ve Operasyon Temsili Süre Bilgileri

\begin{tabular}{|c|c|c|c|c|c|c|c|c|c|c|c|c|c|c|c|c|}
\hline Tipler & & & & & & & & pera & yon & & & & & & & \\
\hline \multirow{2}{*}{ Tip1 } & $\mathrm{M}$ & $\mathrm{M}$ & $\mathrm{M}$ & $\mathrm{M}$ & $\mathrm{M}$ & $\mathrm{M}$ & $\mathrm{M}$ & $\mathrm{M}$ & $\mathrm{M}$ & $\mathrm{M}$ & $\mathrm{M}$ & $\mathrm{M}$ & $\mathrm{M}$ & $\mathrm{M}$ & $\mathrm{M}$ & \\
\hline & 1 & 2 & 3 & 4 & 5 & 7 & 8 & 10 & 12 & 13 & 14 & 15 & 16 & 17 & 18 & \\
\hline Tip1 süre & 32 & 36 & 20 & 28 & 36 & 44 & 70 & 40 & 30 & 34 & 8 & 32 & 20 & 24 & 14 & \\
\hline \multirow{2}{*}{ Tip4 } & $\mathrm{M}$ & $\mathrm{M}$ & $\mathrm{M}$ & $\mathrm{M}$ & $\mathrm{M}$ & $\mathrm{M}$ & $\mathrm{M}$ & $\mathrm{M}$ & $\mathrm{M}$ & $\mathrm{M}$ & $\mathrm{M}$ & $\mathrm{M}$ & $\mathrm{M}$ & $\mathrm{M}$ & $\mathrm{M}$ & $\mathrm{M}$ \\
\hline & 1 & 2 & 3 & 4 & 5 & 6 & 7 & 8 & 10 & 12 & 13 & 14 & 15 & 16 & 17 & 18 \\
\hline Tip4 süre & 52 & 44 & 32 & 32 & 46 & 28 & 54 & 70 & 44 & 30 & 34 & 16 & 34 & 24 & 24 & 14 \\
\hline
\end{tabular}

GA amaç fonksiyonu hesaplaması için kullanılan modelde makinalar mevcutta işlediği ürüne ait parametreleri hafızasında tutarak bir sonraki modele ait parametreleri mevcuttaki parametreler ile karşılaştırmakta, tip değişimi belirten parametre değişimi durumunda da operasyon öncesi tip değişimi işlemi gerçekleştirmektedir. Tip değişim işleminde değişen parametrelere göre süre bilgisi Tablo 6' da tanımlanmaktadır. 7200 satırlık tablodan örnek olması için tablonun bir bölümü gösterilmektedir. Tabloda makina bazlı hangi modelden hangi modele geçerken ne kadar bir süre ayar için harcanacağ 1 bilgisi ürünlerin parametrelerine göre bu tablodan okunarak belirlenmektedir. Ayar geçiş tanımları yönlü olarak yapılmış, bu sayede sıralama bazlı ayar süresi değişen makinalarda bu sürelerin tanım işlemine olanak sağlanmıştır.

Tablo 6. Makina Tip Dönüş Bilgileri

\begin{tabular}{cccccccccc}
\hline \multirow{2}{*}{ Makine } & \multicolumn{3}{c}{ Mevcut Parametreler } & \multicolumn{3}{c}{ Geçilecek Parametreler } & \multirow{2}{*}{ Hazırlık } \\
& Par1 & Par2 & Par3 & Par4 & Par5 & Par6 & Par7 & Par8 & Zamanı \\
\hline M1 & P0-1 & P1-2 & P2-1 & P3-4 & P0-6 & P1-3 & P2-1 & P3-3 & 30 \\
M1 & P0-1 & P1-2 & P2-1 & P3-4 & P0-7 & P1-2 & P2-2 & P3-2 & 1320 \\
M2 & P0-2 & P1-1 & P2-1 & P3-3 & P0-3 & P1-3 & P2-1 & P3-3 & 60 \\
M2 & P0-2 & P1-1 & P2-1 & P3-3 & P0-7 & P1-2 & P2-2 & P3-2 & 312 \\
M2 & P0-2 & P1-1 & P2-1 & P3-3 & P0-1 & P1-4 & P2-2 & P3-1 & 240 \\
M2 & P0-2 & P1-1 & P2-1 & P3-3 & P0-1 & P1-4 & P2-2 & P3-1 & 168 \\
M5 & P0-2 & P1-6 & P2-1 & P3-4 & P0-4 & P1-4 & P2-2 & P3-1 & 55 \\
M15 & P0-3 & P1-1 & P2-1 & P3-3 & 3P0-1 & P1-4 & P2-1 & P3-4 & 25 \\
M18 & P0-3 & P1-1 & P2-1 & P3-3 & 3P0-1 & P1-5 & P2-2 & P3-1 & 0 \\
\hline
\end{tabular}


Üretimi gerçekleştirilecek ürün tanımlamaları Plan Havuzu bölümünden yapılmaktadır. Problemde kullanan plan havuzuna ait tip, adet ve termin bilgileri Tablo 7' de verilmektedir.

Tablo 7. Üretim Planı: Tip, Adet ve Termin Bilgileri

\begin{tabular}{cccccc}
\hline Tip & Adet & Termin & Tip & Adet & Termin \\
\hline Tip1 & 5 & 4000 & Tip11 & 5 & 6000 \\
Tip2 & 5 & 4000 & Tip11 & 5 & 6500 \\
Tip3 & 5 & 4000 & Tip12 & 5 & 6500 \\
Tip4 & 5 & 6000 & Tip13 & 5 & 6500 \\
Tip5 & 5 & 4000 & Tip14 & 5 & 1500 \\
Tip5 & 5 & 5000 & Tip15 & 5 & 1500 \\
Tip6 & 5 & 5000 & Tip16 & 10 & 2500 \\
Tip7 & 5 & 5000 & Tip17 & 10 & 2500 \\
Tip8 & 5 & 4000 & Tip18 & 10 & 6500 \\
Tip8 & 5 & 6000 & Tip19 & 10 & 2500 \\
Tip9 & 5 & 6000 & Tip20 & 10 & 2500 \\
Tip10 & 5 & 2000 & & & \\
\hline
\end{tabular}

Model ile ilgili sürelerin tanımlandığı tüm tablolarda zaman birimi olarak dakika kullanılmıştır. Terminler modelin başlangıç anını 0 noktası kabul edilerek ilgili ürünlerin tamamının teslim edilmesi gereken dakikayı temsil etmektedir. GA amaç fonksiyonu hesaplama modelinde tüm gecikmeler bu dakika bilgisi üzerinden ürünlerin depoya giriş zamanları dikkate alınarak ürün bazlı hesaplanmaktadır.

Planlama havuzuna 20 farklı ürün tipi ile farklı önceliklere sahip 23 farklı sipariş tanımlanmıştır. Toplamda 140 adet olan ürün havuzunun ürün terminleri belli bir önceliklendirme gözetilerek atanmıştır.

\section{GA Çalıştırma Parametrelerinin Değerlendirilmesi}

GA değerlendirmede kullanılan veri setinde bulunan 23 farklı siparişi farklı GA parametreleri ile amaç fonksiyonundaki en az maliyeti yaratacak varyasyonu bulabilmek için farklı parametreler ile testler gerçekleştirilmiştir.

Seçkinlik kullanılmadan yapılan parametre denemeleri sonucunda algoritma daha geniş bir çözüm uzayı aramayı amaçlarken iyi olarak nitelendirilebilecek 5500dk altındaki çözümlere rassal yakınsamalar dışında yaklaşamamıştır. Seçkinliğin getirdiği kısa dönem hafıza yoksunluğu sebebi ile iyi sonuçlar elde edilememiştir. Seçkinliğin popülasyon sayısının \%10'u ve üzerinde kullanıldığı denemelerde ise algoritma lokal optimumlara daha fazla takılma eğilimine girerek daha iyi sonuçlar üretebilmek için göreceli olarak daha fazla iterasyona ihtiyaç duymuştur. 
$\% 80$ çaprazlama ve \%5 mutasyon oranı ile 100 iterasyonluk denemede kullanılan 2 seçkin birey ve 75 bireylik popülasyon ile 4985,475 puan elde edilmiştir. Çözüm için üretilen üretim planında setup zamanlarına ve terminlere göre beklenen Parametre1 gruplaşması gözlemlenebilmiş ancak grupların kendi aralarındaki ayar zamanları değerlendirildiğinde daha iyi alternatiflerin olabileceği gözlemlenmiştir. Bir sonraki deneme çaprazlama ve mutasyon oranları arttırılarak ve popülasyondaki birey sayısı azaltılarak gerçekleştirilmiştir.

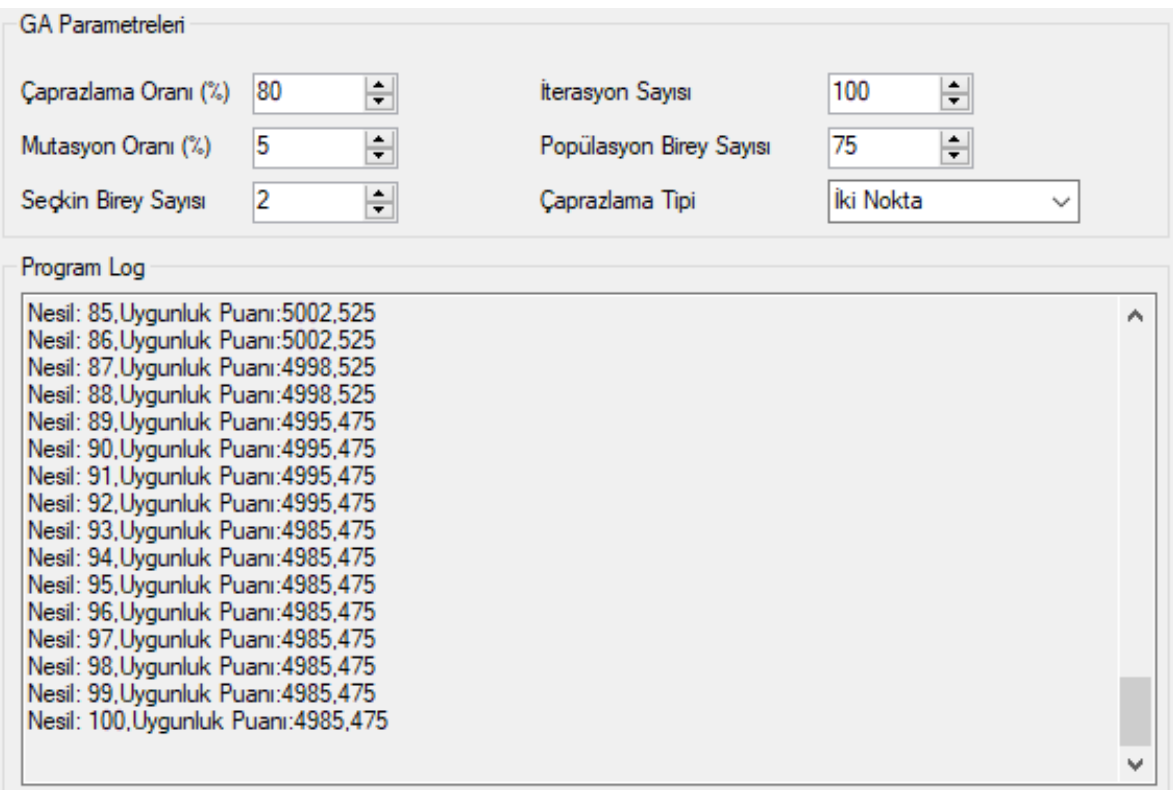

Şekil 10. Test Parametreleri: Batch Bazlı (1)

$\% 90$ çaprazlama ve \%8 mutasyon oranı ile 200 iterasyonluk denemede kullanılan 3 seçkin birey ve 50 bireylik popülasyon ile 4963,475 puan elde edilmiştir. Arttırılan iterasyon sayısı ile daha iyi bir sonuç elde edilebilmiş ancak birey sayısının seçkin birey sayısına oranı sebebi ile daha iyi bir sonuca ulaşmakta zorlanılmıştır.

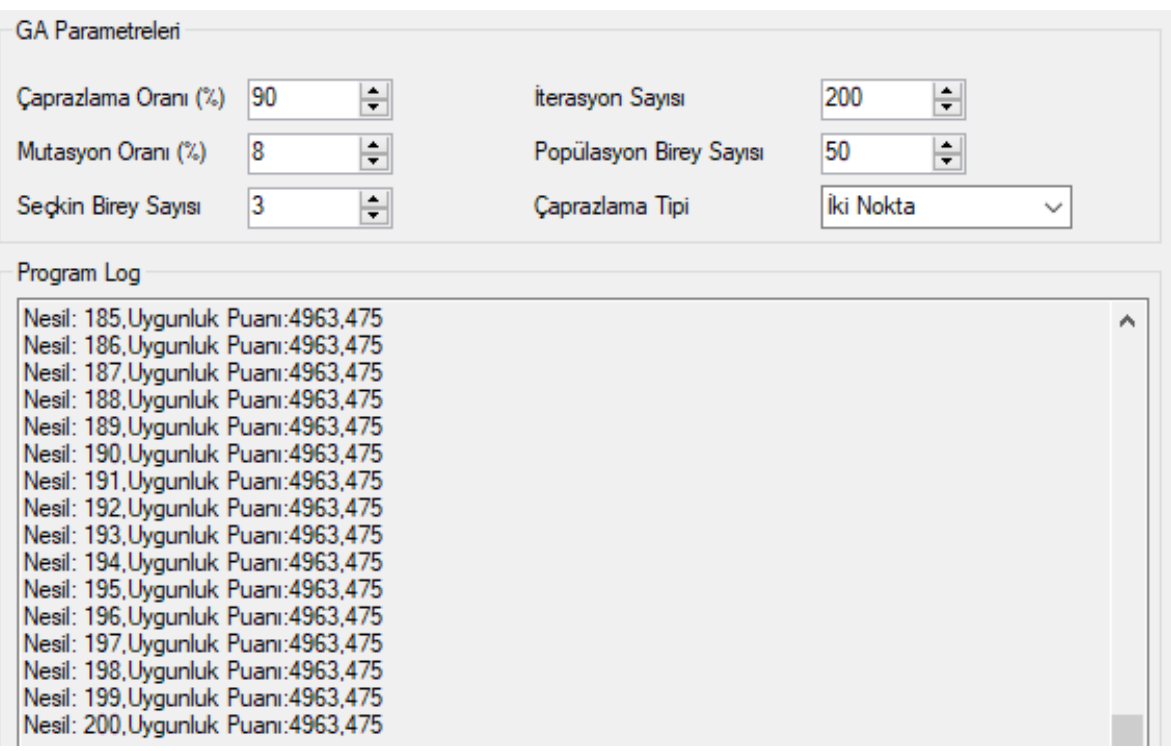

Şekil 11. Test Parametreleri: Batch Bazlı (2) 
$\% 90$ çaprazlama ve \%8 mutasyon oranı ile 500 iterasyonluk denemede kullanılan 3 seçkin birey ve 100 bireylik popülasyon ile 4887,475 puan elde edilmiştir, iterasyon ve popülasyon sayısı arttırıldıkça algoritma daha iyi sonuçlar elde etmeye başlamaktadır. Optimum sonucu bulabilmek için iterasyon sayısı arttırılarak \%90 çaprazlama ve $\% 10$ mutasyon oranı ile 1000 iterasyonluk denemede kullanılan 2 seçkin birey ve 100 bireylik popülasyon ile 4849,475 puan elde edilmiştir. Bu puan hazırlanan veri seti ile batch bazlı planlama kullanılarak ulaşılabilen en yüksek puandır. İterasyon sayısı 1000 üzerine çıkıldığı durumlarda da daha yüksek bir puan elde edilememiştir.

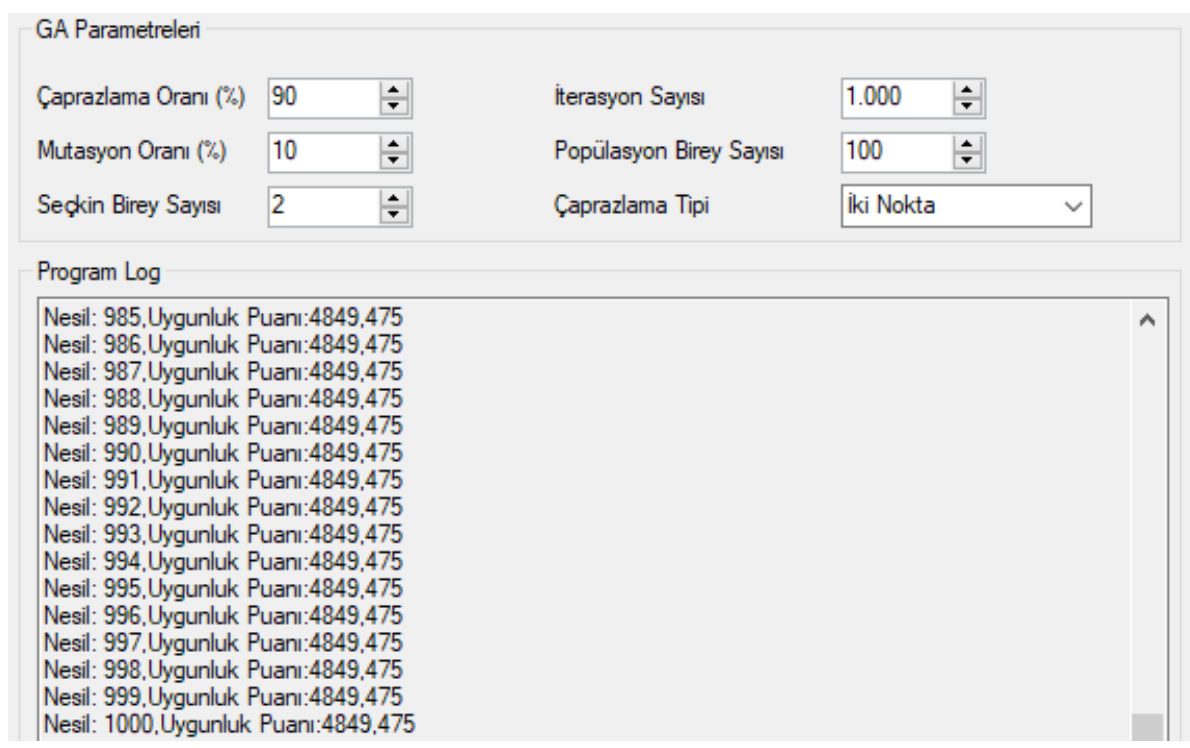

Şekil 12. Test Parametreleri: Batch Bazlı (3)

Ürün karması hesabı yapılabilmesi için kurgulanan diğer versiyonda ise kombinasyon sayısının parti bazlı yönteme göre daha çok olması sebebi ile iterasyon sayısının yüksek tutulması gerekmiştir. \%90 çaprazlama ve \%9 mutasyon oranı ile 2000 iterasyonluk denemede kullanılan 5 seçkin birey ve 100 bireylik popülasyon ile 8267 puan elde edilmiştir.

\section{Sonuç}

Bu çalışmada sıra bazlı değişen tip değişim/ayar sürelerine sahip farklı istasyonlardan oluşan bir üretim hattının GA kullanılarak en az toplam maliyete ulaştıracak çizelge alternatifleri araştırılmıştır. Çalışmada üretim süreleri, kuyruk kapasiteleri, farklı ürün rotaları ve tip değişim süreleri ve bu faktörler göz önünde alınarak üretim hattı içerisinde oluşan alternatif üretim çizelgeleri hesaplayacak bir yapı oluşturularak bu yapı GA'ya entegre edilmiştir.

Kurulan yapı ve hazırlanan optimizasyon algoritması ile üretim hattına ait parti bazlı üretim ve kısa dönemli karma üretim alternatifleri araştırılmıştır. Karma üretim senaryoları daha çok alternatif barındırdığından, algoritmanın iyi sonuç verebilmesi uzun iterasyonlar sonucu gerçekleşebilmektedir. Bu tip bir problemi daha detaylı ele alabilmek için ilerleyen dönemdeki çalışmalarda hibrit genetik algoritma yapıları kullanılarak efektif sonuçlar alınabileceği düşünülmektedir. 
Parti bazlı algoritma kullanılarak gerçek hayata uygun veri seti ile yapılan denemelerde üretim hattının kabul edilebilir sonuçlar üreterek optimize edildiği gözlemlenmiştir. Algoritma en kısa üretim süresinde en az gecikme hedefi ile çalışma parametrelerine bağlı olarak kabul edilebilir lokal optimumlara ulaşabilmektedir. Bu çalışma ile planlama ihtiyaçları hızlı şekilde değişkenlik gösterebilen bir üretim hattında kullanılabilecek bir karar destek sistemi geliştirilmiş, üretim koşullarında hızlı karar alma gerekliliği oluşan durumlarda elle hazırlanabilecek planlardan daha hızlı ve kabul edilebilir sonuçlar elde edilmiştir.

\section{Kaynakça}

Borovska P. (2006). Solving the Travelling Salesman Problem in Parallel by Genetic Algorithm on Multicomputer Cluster. International Conference on Computer Systems and Technologies CompSysTech "e6, 15-16 June 2006, University of Veliko Tarnovo, Bulgaria

Buzacott, J.A., Corsten, H., Gössinger, R., \& Schneider, H.M. (2012). Production Planning and Control: Basics and Concepts. Oldenbourg Verlag.

Coley, D.A. (1999). An Introduction to Genetic Algorithms for Scientists and Engineers, World Scientific.

Emel, G.G., \& Taşkın, Ç. (2002). Genetik Algoritmalar ve Uygulama Alanları. Uludă̆ Üniversitesi İktisadi ve İdari Bilimler Fakültesi Dergisi, 21(1), 129-152.

Gen M., \& Cheng R. (2000). "Genetic algorithms and engineering optimization", John Wiley \& Sons, Inc.

Gonçalves, J.F., de Magalhães Mendes, J.J., \& Resende, M.G. (2005). A hybrid genetic algorithm for the job shop scheduling problem. European journal of operational research, 167(1), 77-95.

Graves, S.C. (1981). A review of Production Scheduling. Operations Research, 29(4), TemmuzAğustos, ss. 646-675.

Hamilton, W.D., \& Ridley, M. (2005). Narrow roads of gene land: the collected papers of W.D. Hamilton, Oxford University Press.

Holland J.H. (1975). Adaptation in Natural and Artificial Systems, University of Michigan Press, Ann Arbor, Michigan.

Hou, E. S., Ansari, N., \& Ren, H. (1994). A genetic algorithm for multiprocessor scheduling. IEEE Transactions on Parallel and Distributed systems, 5(2), 113-120.

Kamauff, J. (2010). Manager's Guide to Operations Management, New York, McGraw-Hill

Kocamaz M., \& Çiçekli U.G. (2010). Paralel Makinaların Genetik Algoritma İle Çizelgelenmesinde Mutasyon Oranının Etkinliği. Ege Akademik Bakış, 10(1):199-210.

Laporte, G., Gendreau, M, Potvin, J.Y., \& Semet, F. (2000). Classical and modern heuristics for the vehicle routing problem. International Transactions in Operatioanal Research, 7: 285-300.

Reeves C.R., \& Rowe J.E. (2003). Genetic Algorithms: Principles and Perspectives; A Guide to GA Theory, Kluwer Academic Publishers, Dordrecht

Russell, R.S., \& Taylor III, B.W. (2000). Operation Management, 4th Edition, Prentice Hall, New Jersey.

Sheikh, K. (2003). Manufacturing Resource Planning(MRP II) With an introduction to ERP, SCM, and CRM, McGraw-Hill.

Sivanandam S.N., \& Deepa S.N. (2008). Introduction to Genetic Algorithms , Springer.

Temiz, İ., \& Erol, S. (2007). Bulanık Akış Tipi Çizelgeleme Problemi İçin Çok Amaçlı Genetik Algoritma. Gazi Üniversitesi Mühendislik ve Mimarlik Fakültesi Dergisi, 22 (4): 855-862.

i, 22 (4): 855-862. 